\title{
Article
}

Margaret F. Sloan*

\section{The Substance of Things Hoped For: Do State Faith-Based and Community Partnership Offices and Liaisons Help Grassroots Organizations Get Federal Funding?}

\begin{abstract}
In response to The White House Office of Faith-Based and Community Initiatives (FBCI, later renamed the Office of Faith-Based and Neighborhood Partnerships, FBNP), many states either created an FBCI office within state government or established a state liaison to the federal program through a nonprofit organization. While the offices have multiple stated goals, the acquisition of federal funding for community organizations within their respective states is a fairly consistent, and critical, goal for most of these offices. Using a multivariate regression model and a survey of state liaison offices, this mixed methods study finds that there is no difference between states with liaisons and states without with respect to federal funding for community organizations in their states and identifies barriers to their successful achievement of funding objectives. A survey of state FBNP offices detailing budgets, staffing, and reporting structures, among other things, indicates that a lack of unrestricted funds, lack of adequate staffing, and decreasing political salience are contributing factors.
\end{abstract}

Keywords: federal grants, community organizations, faith-based organizations, faith-based and neighborhood partnerships, federal funding

*Corresponding author: Margaret F. Sloan, James Madison University, Harrisonburg, VA, USA, E-mail: sloanmf@jmu.edu

The White House Office of Faith-Based and Community Initiatives (FBCI), now the Office of Faith-Based and Neighborhood Partnerships (FBNP), was created via executive order in 2001 by George W. Bush and reestablished by the Obama administration in 2009. Within the first two years of the FBCI program's kickoff at the federal level, many states either created an FBCI office within state government or established a state liaison to the federal program through a nonprofit organization. 
While state contacts and liaisons have multiple goals and priorities (Sager 2007), the acquisition of federal funding for organizations is one goal that is fairly constant across these offices. Although this goal is rarely stated overtly in the executive orders or legislation creating the offices, it is the current beneath a majority of the offices' activities. In Kentucky's enacting legislation, for instance, five of the seven duties of its state FBCI office concern assisting community organizations with some aspects of federal funding. A Wisconsin office newsletter from 2007 stated the "mission of the Office ... is to share information regarding funding opportunities with organizations throughout the state." An Ohio annual report touted technical assistance and funding opportunities accompanied by a lengthy list of grant recipients in the state and advertised Grants and Nonprofits 101 webinars, and a 2006 survey conducted by the Alaska state office listed the top three most useful electronic resources that were a grants newsletter, funding opportunity notifications, and capacity-building links.

Although these are just a few examples, most state offices and liaisons are charged with distributing funding information to organizations, providing technical assistance including training for grant writing and management, and strengthening nonprofit capacity - all activities that should ultimately result in an increase in funding for nonprofits. In light of these emphases, it seems reasonable that these offices should have an impact on the level of federal funding for community organizations in their respective states. Scholarship has examined the political significance and structure of state and liaison offices but has not assessed how well these offices accomplish their goal of connecting community organizations to federal funding.

This article presents a mixed methods study finding that state-level FBCI offices and liaisons do not translate into more federal dollars to organizations within their states. The qualitative analysis uncovers constraints on these offices that may be limiting their effectiveness in achieving funding growth. After a brief discussion of FBCI funding during the early years of implementation, the first section of the article estimates the impact of state-level offices and liaisons against other grant determinants on the amount of federal funding to the states. The next section of the article discusses the multistate survey process and findings. Finally, the article concludes with the policy implications of the research.

This study is relevant and important for scholars of nonprofit policy, bureaucrats, and grassroots organizations for several reasons: (1) For scholars, this research contributes to the scholarly literature in two areas, both federal grants determinants and the implementation and effectiveness of the FBCI program. It also provides some quantitative analysis of $\mathrm{FBCI}$, whereas research in this area has been largely qualitative; (2) Many pressing issues face grassroots nonprofit organizations, including increasing need for services and funding cuts 
(Schneider 2013), so the potential that state-level offices may provide assistance with locating, approaching, and obtaining resources could make a meaningful difference in the financial stability and potentially the sustainability of organizations serving largely at-risk populations. For some faith-based and community partnership organizations that are constantly on the brink of being eliminated, a truly helpful office, adequately staffed and equipped, might impact the ability of such organizations to survive or thrive; (3) Numerous opportunity costs including time and human capital accompanied the creation and implementation of these state contacts. If the policy initiative is providing a positive return for organizations, the most successful "laboratories" at the state level could be implemented on a wider scale. Likewise, if the program is not achieving key goals, it deserves reassessment at the state and federal level.

Several scholars have written at length about the policy environment and development of FBCI (Bartkowski and Regis 1996a, 1996b; Bartkowski 2001; Bielefeld and Cleveland 2013b; Black, Koopman, and Ryden 2004; CarlsonThies 2004; Cnaan and Newman 2010; Dionne and Dilulio 2000; Farris et al. 2004,; Kennedy 2003; Kennedy and Bielefeld 2006; Kramer et al. 2005a, 2005b; Montiel and Wright 2006; Sager 2010; Schneider 2013; Solomon 2003; Wright 2010; Wuthrow 2004), and space does not permit an in-depth discussion here; however, some key points about FBCI funding patterns are necessary to mention. In 2002, the Compassion Capital Fund, one of the major programs of the Office of FBCI, offered funding to religious organizations providing service in one of five priority areas: homelessness, hunger, at-risk children, transition from welfare to work, and intensive services for persons such as addicts and prisoners. These priority areas were aligned with five federal cabinet departments which serve as the primary funding conduits for faithbased programs: Housing and Urban Development (HUD), the Department of Health and Human Services (HHS), the Department of Education (ED), the Department of Justice (DOJ), and the Department of Labor (DOL). Although priorities under the current administration (namely, the role of community organizations in economic recovery, maternal and child care, responsible fatherhood, interfaith dialog, and, most recently, ending human trafficking) differ from the original priorities established under the Bush administration, ${ }^{1}$ grant monies still flow through these and other federal agencies. Funds do not flow through the White House Office with the intention of mitigating any perception of political influence on awards.

1 During the Bush administration, 36 states created liaisons or offices to address faith-based and community initiative needs. According to the 2012 White House web site, 23 states, as well as Puerto Rico and Washington, DC, had state contacts. 
According to White House reports, in 2003, these five agencies (HUD, HHS, ED, DOJ, and DOL) granted a combined total of $\$ 14.5$ billion for social service funding, of which faith-based nonprofits received $\$ 1.17$ billion, or $8.1 \%$ of awarded funds (White House 2004). From fiscal year 2003 to fiscal year 2005, the number of grants to faith-based nonprofits increased by $38 \%$. At the Department of Housing and Human Services, the number of grants allotted to faith-based organizations increased by $82 \%$ from 2002 to 2005 and the dollars awarded over the same time period increased by $64 \%$. Interestingly, despite the amount of attention focused on religious organizations, 85\% of the funding documented by the White House during this time went to secular organizations. ${ }^{2}$

Beginning with Welfare Reform in 1996 and the creation of Charitable Choice, states began to consider how they might filter the promised federal funding to service organizations in their respective states. Implementation of the initiative differed across states according to political climate, state contracting policies and procedures, and current networks of service providers (Kennedy and Bielefeld 2006) and was also impacted by the employment history of the state program coordinator, the rural or urban setting for the FBCI office, and welfare constraints within the states (Kinney 2006). Although in 1997, no states appropriated funds for faith-based efforts, by 2010 sixteen states had set aside monies for such activities (Sager 2010).

\section{$\mathrm{FBCl}$ funding influences, a quantitative analysis}

Because FBCI liaisons and offices provide information on grants opportunities and technical support to organizations including grant assistance, it is reasonable to expect that the presence of a state-level office or liaison, if utilized, would favorably impact a state's allocation of FBCI funding. Having such a designated individual or office might also signal a measure of support and cooperation for the federal initiative which could have a positive influence on monies awarded within a state, and scholastic literature (Bickers and Stein 2004; Pipes and Ebaugh 2002) supports the argument that cooperative behavior and collective action are determinants of federal awards. ${ }^{3}$

2 The Quiet Revolution report (p. 61).

3 Bickers and Stein indicate that for local governments, cooperation with other governments and organizations is a key variable in achieving greater federal funding (Bickers and Stein 2004). Such cooperation has also been demonstrated as a factor in successful funding in the nonprofit sector (Pipes and Ebaugh 2002). Bickers and Stein's research determines that, in addition to partisan interests in specific grant programs, collective action on the part of grant 
While the presence of a state liaison or office is the variable of primary interest, there are many other reasons why funding might be awarded to organizations, including nonprofit sector capacity, redistributional policies, or political favor. For example, a funding award might reflect an agency's desire to help those most in need, an organization's expertise in completing a grant application, or an agency's interest in supporting organizations with a particular political agenda. Academic research has examined many of these considerations over the past 30 years. ${ }^{4}$ While earlier scholarship focused primarily on political

seeking agencies positively impacts grant awards. They also surmise that over an extended period of time such collaborative efforts will earn a positive reputation for the cooperating agencies, so that government funding agencies will view them favorably when new initiatives or requests for funding arise. Within the nonprofit sector, Pipes and Ebaugh's qualitative study of faith-based coalitions in Harris County, Texas documents the intricacies inherent in managing such cooperative partnerships and how the formation of a coalition assists many organizations in acquiring federal funding. After joining a coalition, some organizations chose not to pursue federal funds to maintain religious autonomy; however, more than half of the interfaith coalitions studied successfully applied for and managed federal monies. Such cooperation on grant applications also indicates a higher level of grantsmanship among successful organizations.

4 Grants literature regarding the public sector has demonstrated the impact of several variables on the receipt of federal funds, including politics and need. However, these public sector impacts have not been tested solely within the nonprofit sector to ascertain whether the same criteria stimulate the allocation of federal dollars to nongovernmental organizations. Much of the public sector grants literature is program specific and not always applicable across a broad spectrum of grants structures simply because of the wide variability between program guidelines and whether or not monies are the result of a competitive process or a congressionally directed appropriation, often known as an earmark. In addition to extending this particular grants discussion into the nonprofit sector, the data available in the current study reverse the program-specific trend by providing an overview across multiple programs and multiple types of organizations.

Public sector models of grant relationships often include political variables. For example, in their study of Australian intergovernmental grants, Worthington and Dollery (1998) find that politicians utilize grant awards to further their goals for reelection. Other political scientists have also teased out the effect of politics as determinants of grant funding (Alperovich 1984; Engstrom and Vanberg 2007; Gist and Hill 1981; Hall 2008, 2010; Holcombe and Zardkoohi 2001; Rich 1989) versus the funding formulas employed by agencies that often have a redistributional mission and include need-based criteria. Many studies find concurrent impacts of need and political determinants, although each may have varying levels of statistical strength. For example, Alperovich's (1984) study finds that "government seeks to maximize the welfare of the population" (p. 285) as well as prospects for reelection. Jennings et al.'s study of the devolution of HUD's Community Development Block Grant program administration from the federal to state level found that programs administered at the state-level tended to fund projects in areas with higher poverty populations and more substandard housing indicating that need-based criteria are more important as the level of administration moves closer to the population being served (Jennings et al. 1986). These criteria are closely aligned with the faith-based and community initiative target clients and so lead to the expectation that need-based criteria will be important in FBCI funding 
and need-based determinants of grant distributions (Alperovich 1984; Engstrom and Vanberg 2007; Gist and Hill 1981; Holcombe and Zardkoohi 2001; Jennings et al. 1986; Rich 1989; Worthington and Dollery 1998), more recent scholarship incorporates a broader swath of considerations (Hall 2008, 2010) including institutional capacity measures. Research also demonstrates a link between nonprofit capacity within a state and federal funding (Luksetich 2008). Therefore, the final criterion that would theoretically impact the receipt of federal funds is the capacity of the sector including its size, the scope of service delivery, and professionalism of organization staff.

Does the presence of an FBCI state office or liaison influence the amount of funding a state's organizations receives? And, what criteria most strongly influence the federal funding of FBCI? Based on the theoretical foundations, this study hypothesizes that the presence of a state White House FBCI liaison or office has a positive relationship with the amount of FBCI grants awarded in that state.

Using the state-level data, the following model is estimated:

Aggregate state grants $=\beta_{0}+\beta_{1} \gamma+\beta_{2} \delta+\beta_{3} \lambda+\beta_{4} \kappa+\varepsilon$

where

$\gamma=$ state liaison/office presence

$\delta=$ state need characteristics

$\lambda=$ political characteristics

$\kappa=$ state nonprofit sector characteristics

$\varepsilon=$ error term

allocations. While these discussions are entrenched in the perspective of the supplier of federal monies, namely the federal government's concerns and rationale for providing funds, some scholars explore other demand-side variables. Rich (1989) explores features of the recipient jurisdictions rather than aspects of federal programs and Stein (1981) illuminates the costs for grant seekers and reconciles the demand and supply factors. Stein asks questions regarding a community's history of receiving federal funds, the impacts of the grants application process on distribution decisions, and a community's prior experience with government programs. Although Stein applies these questions to municipal governments, they potentially have some application for the nonprofit sector as well. In his conclusions, Stein demonstrates that block and revenuesharing grants distribute funds to communities most in need, asserting that political variables are not as powerful in these instances. Stein also concludes within this study that a community's history of receiving grant funding significantly impacts both the decision to apply and the amount of funding received by the federal government. Evidence also exists within the nonprofit sector that prior funding encourages the subsequent application and acquisition of federal funding (Kennedy 2003). Although the history of funding is not an element which can be tested within this study's dataset, it is an important factor to consider for further study. 


\section{Description of measures}

The presence or absence of a state-level office of FBCI or faith-based liaison for the state serves as the primary variable of interest. These data were derived from the White House FBCI web site during the years of study, 2005-2007, and crosschecked with Sager's (2010) descriptive tables. By coding the state office and liaison as separate variables, the model also accounts for any differential impacts in these two types of office structures.

Because FBCI funding received wide bipartisan support, the effects one might attribute to political favoritism by conservative leadership should be mitigated. Yet, political determinants have been demonstrated to have strength within a variety of grant contexts, and Sager (2010) reports that conservative states have a higher likelihood of having an FBCI office. For this study, the political variables are comprised of the state indices for government ideology index and citizen ideology as developed by Berry et al. (1998) for the years 2005 and 2006. These ideology indices are derived for each state using the "roll call voting scores of state congressional delegations, the outcomes of congressional elections, the partisan division of state legislatures, the party of the governor, and various assumptions regarding voters and state political elites" (p. 327). The government ideology index measures political power elites on a continuum between conservative (0) and liberal (1). The citizen ideology index does the same for the collective ideology of private citizens residing within the state. Although these indices are correlated at the 0.4 level, enough variability exists between the two so that both can benefit the model. This is an important distinction, particularly since political leadership can be at times farther on one end of the ideological spectrum than the majority of a state's citizens. Because these indices already encompass a variety of political indicators, no other political variables are used to preserve the parsimony of the model.

The state need characteristics include standard demographic indicators such as population, percentage impoverished, and percentage urban as indicators of need. In addition, to capture the faith-based component of funding decisions the model incorporates a measure of the religiosity of the state's population through the number of congregations per capita as measured by the Association of Religion Data Archives. ${ }^{5}$ An index was created to reflect each state's relative standing regarding

5 The model was originally tested also using the percentage of Christian adherents within a state as an independent variable as derived from US Census data. This variable is interesting, because there are no obvious patterns across the states as one might assume. For example, general wisdom would indicate that more conservative states in the southern part of the United States, the so-called "Bible Belt," might claim a higher percentage of Christian adherents than more liberal or northern states; however, this pattern does not emerge with the present data. In 
the five priority areas for the FBCI under the Bush administration: homelessness, hunger, at-risk children, transition from welfare to work, and services for addicts and prisoners. The index includes state-level data from the Bureau of Justice on total violent and property crimes, US Substance Abuse and Mental Health Services on percentage addicted, percent living in chronic homelessness, and unemployment rates, US Department of Agriculture data on percentage of food insufficiency, as well as the Human Development Index Measure of America 2010 data files regarding the percentage of child poverty, percentage of low birth weight babies, percentage on food stamps, the state high school drop-out rate, and percentage children on Medicaid. The index was created using the aggregate method which is consistent with the literature (Searle et al. 2008; Steenbergen et al. 2003).

Finally, to assess nonprofit capacity, the average nonprofit executive compensation per state, the number of nonprofit organizations per capita filing 990 forms with the Internal Revenue Service, and volunteers per capita are used to measure the capacity of the sector. States with larger nonprofit revenues and more competition among public charities could be perceived as having a higher capacity to compete for federal funds or raise revenues. Therefore, since organizations filing the 990 must meet a minimum requirement of $\$ 25,000$ annually in revenues, the number of organizations filing with the Internal Revenue Service demonstrates higher capacity for receiving grant funds than the alternate statistic of the total number of nonprofits within a state. Executive compensation can serve as a proxy for organizational capacity, since higher paid CEOs would arguably often govern a larger staff and have greater responsibility for fundraising relative to other CEOs. The executive compensation average per state is derived from the National Center for Charitable Statistics using the Sector Analysis tool. A higher number of volunteers indicate greater support for nonprofit efforts within a state. Volunteers provide valuable service to organizations that may lack a budget to pay additional staff for some tasks, and, therefore, increase the capacity of organizations both at the low and at the high ends of the budget spectrum (Preston 2007). These variables offer insight into the relative size and scope of the sector among the states.

Other data for this research are obtained from the White House Office of FBCI report, “The Quiet Revolution: The President's Faith-Based and Community Initiative: A Seven-Year Progress Report” (2008a, 2008b). ${ }^{6}$ These reports contain

initial model specification, the Christian adherents variable neither added strength to the model nor demonstrated significance in preliminary regression.

6 The White House report, by classifying funding as either directed to secular or faith-based organizations is unique and offers an alternative to the difficulties of classifying faith-based organizations (see Bielefeld and Cleveland 2013a). Roundtable on Religion and Social Welfare 
aggregate state-level data for 2005-2006 and single year data for 2007 including:

- the total amount of the awards per state,

- amount of awards to secular nonprofits per state,

- amount of awards to faith-based nonprofits per state, and

- number of volunteers per state.

Only competitive, non-formula grants awarded to an organization as the fiduciary agent are included in the report data. The variables for amount of awards to secular nonprofits and amount of awards to faith-based nonprofits are totaled to create the aggregate amount of awards per state which serves as the primary dependent variable (Figure 1).

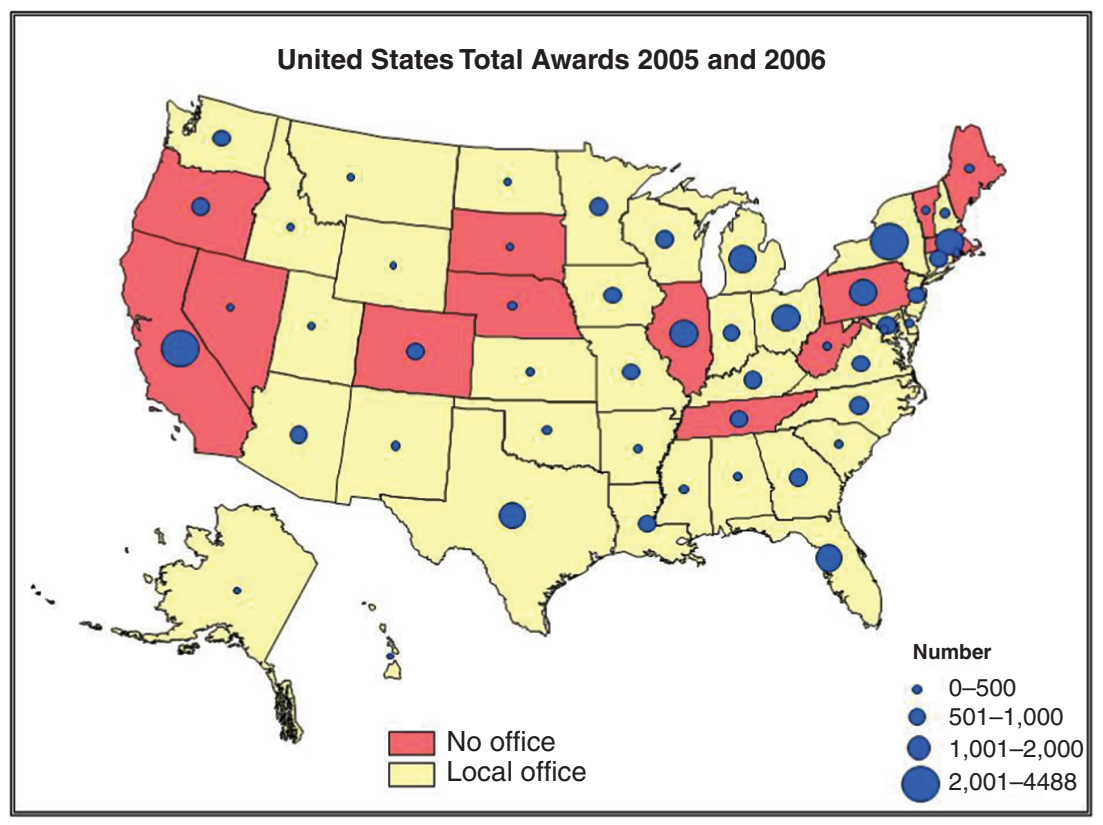

Figure 1: State-level $\mathrm{FBCl}$ offices and number of state awards

Note: The figure notes the state-level offices and liaisons during 2005-2006, which correspond to data used in the empirical model.

Policy report, Taking Stock: The Bush Faith-Based Initiative and What Lies Ahead by David J. Wright discusses problems with this data (p. 73). Montiel and Wright (2006) also discuss the difficulties the government has in identifying faith-based nature of contractors and grantees. 
To eliminate the multicollinearity among the variables of population, volunteers, and number of nonprofits, but still maintain them as theoretically consistent within the model, these three variables were combined into two new variables: volunteers per capita and nonprofits per capita. In this way, these three aspects which are deemed important to understanding funding decisions are estimated appropriately. With these variable transformations, the volunteers per capita variable has a 0.4436 correlation with the amount funded, and the nonprofits per capita variables has a 0.3082 correlation with the dependent variable. $^{7}$ The dependent variable is federal funding per capita. Table 1 describes selected variables used for this study, and Table 2 provides descriptive statistics for the variables. ${ }^{8}$

To allow for adequate variability in the explanatory variables, particularly those which did not change from year to year (such as population, percentage poverty, number of volunteer hours, percentage urban, number of nonprofits filing, and presence or absence of FBCI office) as well as those which experience incremental change each year like the citizen and institutional ideology indices, the total funding over the years studied was combined into a single observation for each state.

An ordinary least squares regression was applied to the state-level dataset with the amount of federal funding per capita as the dependent variable. ${ }^{9}$ Multiple models were employed in order to break out the amount of federal funding by secular and faith-based organization types. In Model 1, the dependent variable is the full amount of federal funds per capita allotted through the

7 High correlation existed within the original dataset among three independent variables with each other and with the dependent variable. State population is correlated with funding amount at 0.9731 as well as with the number of nonprofits filing at 0.9654 . In addition, the number of nonprofits filing was correlated with the dependent variable at 0.9670 and the number of volunteers per state at 0.9763 . This demonstrates that highly populated states have more nonprofit organizations and receive more federal funding relative to states with fewer people and fewer nonprofits. When controlling for population, some states do receive more federal money relative to others as demonstrated in Table 1. These combined variables also decrease the overall variance inflation factor of the model from 12.7 to 2.5 .

8 As can be noted in the table of descriptive statistics, the amount of federal funding is highly skewed right. The mean is 621.007 with a large standard deviation of 638.570 . Therefore, the median of 467.140 has been included as a more instructive statistic for a non-normal distribution and demonstrates that the midpoint for the dataset is $\$ 467$ million in funding per state. The variable transformations carry the additional benefit of normalizing the nonprofits per state and volunteers per state variables which are skewed right in their original form.

9 The Box Cox test supported that a linear model was the best fit. 


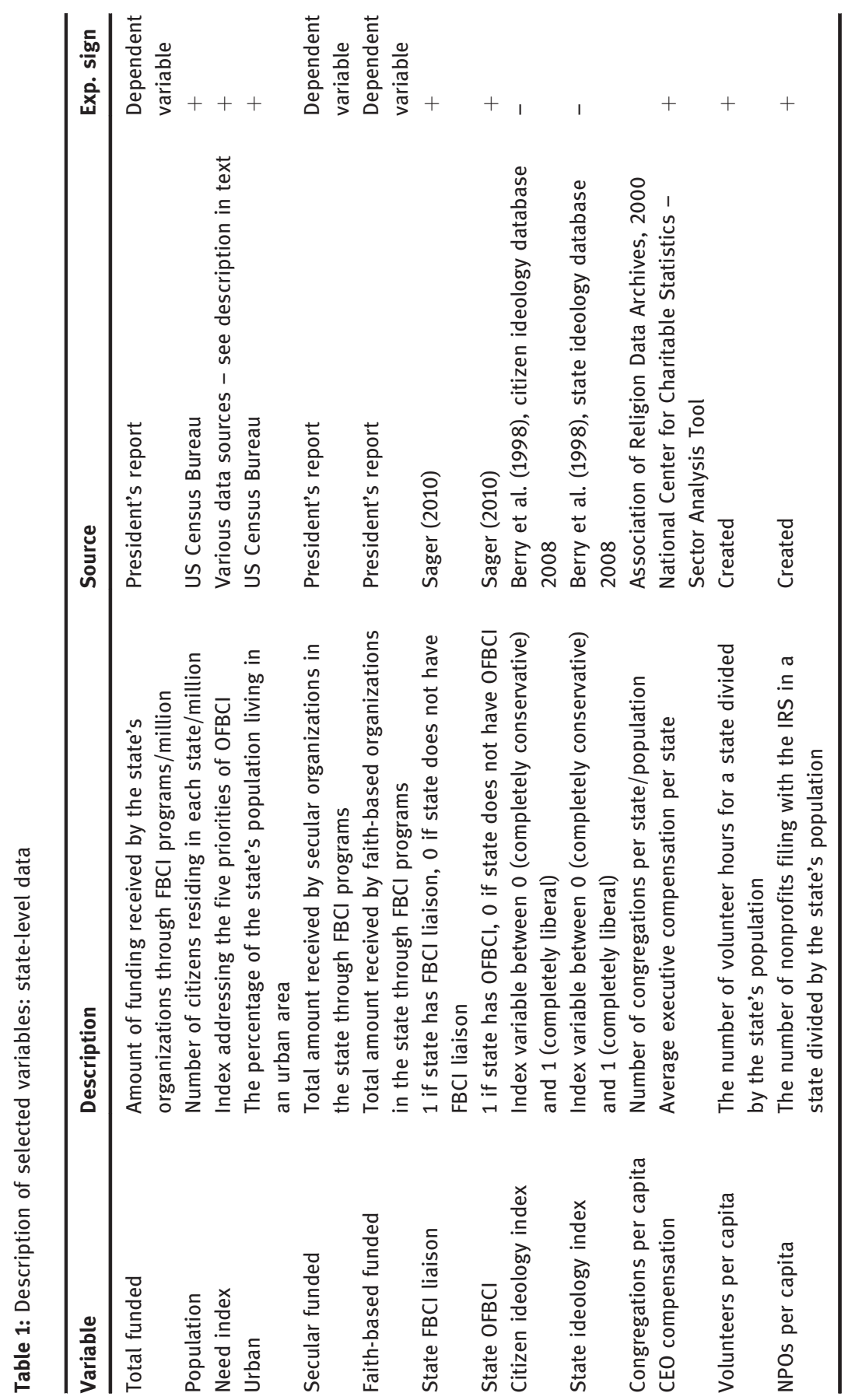


Table 2: Descriptive statistics for variables

\begin{tabular}{lrrrrr}
\hline Variable & Mean & Median & Std. Dev. & Min. & Max. \\
\hline FBCl office & 0.480 & 0.000 & 0.505 & 0.000 & 1.000 \\
FBCI liaison & 0.740 & 1.000 & 0.443 & 0.000 & 1.000 \\
Population & 5.976 & 4.247 & 6.662 & 0.515 & 36.458 \\
Need index & 0.105 & 0.099 & 0.020 & 0.076 & 0.176 \\
CEO compensation & $140,822.000$ & $137,620.500$ & $34,948.030$ & $79,306.000$ & $300,462.000$ \\
Poverty & 12.232 & 11.6 & 2.828 & 6.600 & 19.300 \\
Urban & 71.964 & 71.5 & 14.902 & 38.200 & 94.400 \\
Citizen index & 52.053 & 50.761 & 14.921 & 25.532 & 90.530 \\
State ideology index & 48.830 & 48.915 & 24.602 & 10.247 & 88.091 \\
NPOs per capita & 0.002 & 0.002 & 0.001 & 0.001 & 0.004 \\
Congregations per & 0.001 & 0.001 & 0.000 & 0.000 & 0.002 \\
$\quad$ capita & & & & & \\
Volunteers per capita & 0.224 & 0.222 & 0.0480 & 0.128 & 0.311 \\
Total funded & 621.009 & 467.140 & 638.570 & 64.359 & 346.341 \\
Secular funded & 537.690 & 420.380 & 546.299 & 60.885 & $2,994.003$ \\
Faith-based funded & 83.318 & 39.261 & 110.217 & 0.892 & 472.702 \\
\hline
\end{tabular}

Note: $N=50$.

program; in Model 2, the dependent variable is only the portion of total funding awarded to secular organizations per capita; and in Model 3, the portion of total funding awarded to faith-based organizations per capita is the dependent variable. The results of the regressions for each model are given in Table 3. This set of models explains $14 \%$ of the variance on the faith-based funding alone and $65 \%$ for the total funding per capita.

\section{Results for quantitative analysis}

Regarding the primary variable of interest, the average level of funding is the same for states with an office or liaison and states without. These state contacts, although they offer varied services to help develop grant resources for community and faith-based initiatives within a state, do not make a difference in terms of how much money, on average, a state receives through the 11 participating federal agencies. Because such offices were designed, in part, to offer assistance to organizations in seeking grant funds, these results warrant further investigation and motivate the qualitative portion of this study. Interestingly, the coefficient for the nonprofit liaison structure has a negative coefficient, while the state government office structure has a positive one indicating that there may be some 
Table 3: Results for Models 1-3, federal funds per capita as dependent variable

\begin{tabular}{|c|c|c|c|}
\hline \multirow[t]{3}{*}{ Dependent variable } & \multicolumn{3}{|c|}{ Models of grants determinants } \\
\hline & Model 1 & Model 2 & Model 3 \\
\hline & Total funding & Secular funding & Faith-based funding \\
\hline Population & $\star \star \star-1.695$ & $\star \star \star-1.677$ & -0.019 \\
\hline Need index & $\star \star \star 1,623.729$ & $\star \star \star 1,549.124$ & 74.810 \\
\hline $\begin{array}{l}\text { Nonprofit organizations } \\
\text { per capita }\end{array}$ & $\star \star \star 46,278.78$ & $\star \star \star 43,935.33$ & $2,349.673$ \\
\hline Volunteers per capita & -167.285 & -129.290 & -38.026 \\
\hline $\begin{array}{l}\text { Average nonprofit CEO } \\
\text { compensation }\end{array}$ & $\star \star \star *-0.000$ & $\star * *-0.000$ & 0.000 \\
\hline $\begin{array}{l}\text { Percentage of urban } \\
\text { population }\end{array}$ & -0.310 & -0.386 & 0.075 \\
\hline Congregations per capita & *-0.029 & *-0.028 & -0.001 \\
\hline Citizen ideology index & -0.331 & -0.313 & -0.018 \\
\hline Institutional ideology index & -0.258 & -0.252 & -0.006 \\
\hline State $\mathrm{FBCl}$ liaison & -6.078 & -8.390 & 2.309 \\
\hline $\mathrm{OFBCI}$ & 7.010 & 5.712 & 1.302 \\
\hline Cons & 13.602 & 15.548 & -1.890 \\
\hline$R$-squared & 0.650 & 0.650 & 0.142 \\
\hline
\end{tabular}

Notes: $N=50 ;{ }^{*}$ Within $90 \%$ confidence; ${ }^{* \star *}$ Within $95 \%$ confidence.

difference between the liaison and state office structures relative to funding that should be examined.

The research also indicates that FBCI federal funds were expended in keeping with programmatic priorities as demonstrated by the high significance of the need index in Models 1 and 2. A 1\% increase in the need index corresponds with an increase of $\$ 1.623$ million in funding for Model 1 and \$1.594 in Model 2. Therefore, federal funds counted in the FBCI assessment were reaching the program's priority areas where homelessness, at-risk youth, services for addicts and prisoners, welfare to work, and hunger. While total funding increases with an increase in population, the population coefficient is negative indicating that every increase of one million people corresponds with a decrease of \$1.69 in funding per capita in Model 1 and \$1.67 in Model 2. In other words, as the population increases, there is less money distributed per person within a state. In keeping with prior research, this study affirms that needs assessment is consistently important in funding decisions. The significance of the need and population speaks to the dominance of redistributional concerns in this basket of programs. 
Results also largely confirm that the greater the capacity of the sector the more funds the state will receive. In Models 1 and 2, the number of nonprofit organizations per capita, the average CEO compensation, and number of congregations per capita achieve statistical significance. Funding per capita increases by $\$ 46,278$ for every increase of one nonprofit filing with the IRS. Regarding congregations, each additional congregation decreases funding by $\$ 0.029$ per capita; however, overall federal funding to congregations increased. Finally, average nonprofit CEO compensation was found to be highly significant to Models 1 and 2, with a positive coefficient. Volunteers per capita did not attain significance in either of the models. These findings indicate that the structure of the nonprofit sector itself has some bearing on federal funding, and states without a thriving nonprofit sector are at a disadvantage in this regard ${ }^{10}$ which is consistent with literature that demonstrates the relationship between federal government and nonprofit capacity.

The current models do not reinforce the role of politics as a determining factor in federal funding decisions for this bundle of grant programs. Neither a state's conservative leadership nor its citizen preferences for conservative policy has a significant relationship with the dependent variable, although the signs for both variables are negative, as expected.

When the independent variables are regressed on the funding awarded to only the secular organizations in the dataset (Model 2), the significant coefficients remain constant. Approximately $85 \%$ of the awards made were for secular organizations, so this constancy was expected. Interestingly, no variables attain significance in Model 3, when the dependent variable is funding to faith-based organizations only, a finding that supports a qualitative study by Sinha (2013) where only a small subset of African American faith-based organizations in a sample of religiously identified organizations had increased their proportion of public funding since the establishment of federal faith-based policies. This finding has implications for further research and will be discussed later.

Since the quantitative assessment indicates that state-level offices and liaisons are not helping state faith-based and community organizations to receive more federal grant money, the qualitative analysis seeks to understand some of the descriptive characteristics of these offices to identify discernible patterns

10 A model was estimated utilizing the total number of awards per capita instead of the total funding per capita resulting in significance at the $95 \%$ confidence level only for the number of nonprofits per capita and average executive compensation for nonprofits within a state. These results yield additional support to the importance of nonprofit sector characteristics on the number of awards. 
that may help explain why there is no difference between states with offices or liaisons and states without relative to funding levels.

\section{Descriptive characteristics of FBNP state offices}

In order to better assess the impact of the state-level liaisons, data were gathered from the 2010 state liaison contacts as listed on the White House Office of FBNP web site. Surveys were emailed to the 29 FBNP state contacts $^{11}$ (22 state offices and 7 liaisons), with reminder notices following 2 weeks and 4 weeks later to those who did not respond to the survey. For those still not responding, followup phone calls were made between October 2010 and February 2011.

Since problem areas for email surveys include failure to complete (Kaplowitz, Hadlock, and Levine 2004), special care was taken with survey construction to mitigate complex questions and length which might deter participants from completing the answers. Therefore, the survey contained a short series of open-ended questions to maximize the opportunity for each survey respondent to elaborate on their particular environment and circumstances while being mindful of the time commitment required to participate (see Appendix for a copy of the survey instrument). If a survey respondent left a question unanswered, the survey data were augmented with data from that state contact's web sites, reports, and state budget documents when available. Therefore, 15 states have budget information included in this study for a $52 \%$ overall survey response rate for liaisons and state offices. The majority of responses $(77 \%)$ were from state offices with the remaining four responses coming from liaisons outside of government.

Two state offices that responded to the survey are no longer listed on the White House office list of state contacts.

Taking a modified grounded theory approach, data were triangulated from the surveys identifying common themes and key words. Interview content was coded and analyzed first for key words and concepts. After initial coding, the researcher moved on to axial coding in which the concepts identified earlier are examined for linkages and relationships among concepts. Analysis also included graphical depictions of financial and staffing data to detect trends. Responses were geographically diverse and represent a wide variance in terms of funding, staffing, placement in or outside of government, and services.

11 Although the number of state contacts has fluctuated, as noted, the number of state contacts listed at the time of survey distribution was 29 . 


\section{Results of qualitative analysis}

State FBNP offices rely on a variety of funding sources, or indeed, in some cases almost no funding sources. General funds are used to support $26.7 \%$ of survey respondents with 13\% relying solely on general funds to operate. Budgets reportedly range from $\$ 0$ to $\$ 7$ million with the larger figures connoting federal grant monies for administering social service programs.

Seven of the respondents reported having no budgets (46.6\%), four reported budgets of less than $\$ 350,000$ (26.7\%), and four reported budgets of $\$ 1$ million or more $(26.7 \%)$. Seven respondents $(46.6 \%)$ are funded, at least in part, by federal grants or contracts with $100 \%$ of those reporting more than a million dollars in budget relying on federal funding in some form. Seventy-five percent of those reporting less than $\$ 1$ million in budget are supported by grants in some way. The majority of federal financing comes from programs such as Americorps, Temporary Assistance for Needy Families, and the HHS. One state indicated receiving its entire budget through the American Economic Recovery Act Nonprofit Capacity-Building grant program. Only one office reported having any private grant funding.

In offices with small budgets much, if not all, of the funds support a portion of staff and in some cases cover some office supplies. Similarly, Sager's work found that six state FBCI offices had budgets which only covered direct salaries (Sager 2010). In the current study, few reported having budgeted travel monies, limiting technical assistance to in-office service. While internal operations are meagerly funded, the same is true for external activities meaning the offices predominantly provide low-cost services. For example, some offices reported providing no direct services to organizations, concentrating rather on "general awareness campaigns" and using partnerships to create service opportunities. One office provides an electronic newsletter for nonprofits containing a list of grant opportunities with links to federal agency information along with web resources. Several of the offices offer free or low-cost training programs for nonprofits and/or one-on-one technical assistance on demand. Other offices simply serve as advisors to the Governor, agencies within the executive branch, and members of the legislature with no direct service to organizations.

While several offices demonstrate a concerning lack of resources and staff, those located within a governor's office have greater revenues and staff capacity. In perhaps the best example of diverse revenue streams, one Midwestern state has an office with several million dollars in revenue streaming from a mixture of some general funds, a federal grant and two private grant sources. As a result, this office has a staff of eight full-time individuals and offers a number of services to community organizations within their borders. In contrast, liaisons 
located in nonprofit organizations had a much smaller average budget (ranging between $\$ 0$ and $\$ 200,000$ per year) and no full-time staff.

The budgets directly impact how many people are devoted to faith-based and community organizations within each state. Staffing in these offices ranges from one part-time employee to twenty-five individuals. Of those individuals designated as state office employees by respondents, time allocated specifically to FBNP activities is meager. Of the sample, $2 / 3$ of the offices were spending $50 \%$ or less of their time on FBNP activities, almost a third spent $20 \%$ or less of their time on FBNP, and only three offices responded they spend $81-100 \%$ of their time on FBNP activities. The two offices reporting the largest number of employees (10 and 25) spent only $21-40 \%$ of time working with FBNP specifically. This indicates that offices are largely fragmented in their FBNP efforts and responsibilities, sharing time with a variety of other human service efforts within the state.

Where individuals' time is shared between FBNP activities and elsewhere, generally the activities are also related to social service and volunteerism. For example, time allocated to other activities includes the State Commission on National and Community Service, State Service Commission, Volunteer Action, Governor's Mentoring Partnership, State Agency Volunteer Forum, state Department of Human Services, as well as outreach and other special programs. The relationship between state offices and the federal office operates more tangentially than directly, with most contact coming through the federal agency FBNP liaisons. State offices report participation on conference calls and direct contact with program officers as their primary contacts with the federal program, particularly the regional or local branch offices of these agencies such as Health and Human Services (HHS), HUD, FEMA, United States Department of Agriculture, Substance Abuse and Mental Health Services Administration (SAMHSA), DOL, and Corporation for National and Community Service.

In terms of communicating grant opportunities, there is an indication that the federal agency FBNP liaisons in their respective agencies are helpful resources for the state directors. One director writes, "We have partnered with SAMHSA to host a state capacity building training, SBA's local office to engage the faith community, Federal Bureau of Prisons through our prisoner reentry initiatives, DOL through our quarterly faith liaison meetings, and many conference calls with various federal agencies.”

\section{Implications of qualitative analysis}

Overall, survey results indicate that several factors may be hindering FBNP state offices from favorably impacting a state's allocation of FBCI funding. A lack of 
financial and human resources is perhaps the greatest obstacle, with the lack of resources for FBNP state offices further strained by an overreliance on a single source of income and loss of political salience.

Although state offices are funded overall by a variety of sources, individual offices do not have a great deal of revenue diversity. Within the state offices responding to the survey, in most cases greater than $50 \%$ of the budget revenue was from a single source, and in some cases a single grant source provides $100 \%$ of the office's funding. On the positive side, governmental grant funding which dominates much of the FBNP office budgets has the potential to provide longterm stable funding (Gronbjerg 1993; Rushton and Brooks 2007) and resource dependence on federal grants is mitigated when funds are received from multiple federal agencies. However, restrictions on these funds may prohibit their use for furthering the stated goals of these offices, inhibiting their ability to carry out their mission. Mission drift can also occur if the state office or liaison shifts its priorities to align with funding opportunities. Each office must weigh the benefits and challenges of various funding streams including their long-term stability and fit with the stated mission.

Keeping the benefits and challenges in mind, state offices could seek out more sources of income in the form of fees for service, greater diversification of grants, or other resource streams (Young 2007). While grant reliance within a state agency is not as potentially dangerous as for a nonprofit organization because of the greater number of safety nets within state government and the importance of political favor in the budgeting process, over the long-term fiscal indiscipline could damage the status of the office and lead to a threat of mortality in the absence of political favor.

Better communication between state liaisons and the White House FBNP Office also seems needed. Although a 2010 report by the Obama administration task force for FBNP makes several recommendations for improving the operations, services, and accountability of the White House FBNP Office, ${ }^{12}$ including working more closely with organizations within the states, none of the recommendations discuss the state liaisons or strengthening the ties between the state and federal office. Further evidence of this disconnect between the two is evidenced by contact information listed on the White House web site for liaisons being inaccurate in some cases, indicating that such offices are lacking in consistency and not working with the White House office in a meaningful way. And although $47 \%$ of respondents said there was no change in the office's work from the Bush administration to the Obama administration, over half of

12 President's Advisory Council on Faith-Based and Neighborhood Partnerships (2010). 
respondents did say there was "less push from the national level" with one director summing up the current situation by writing:

There are fewer communications from the present White House office, fewer pieces of information to pass on, less requested feedback to Washington, less information about grants that are available, less information about issues of importance to faith-based and community organizations.

Some FBNP offices have enjoyed several years of seemingly strong gubernatorial support, with a direct reporting line to the governor and some of the larger state appropriations reported in the survey. Four state offices reporting directly to the governor have received such multi-year appropriations, and the state of New Jersey has appropriated \$3 million per year since 1998 (Sager 2010). Just as the number of state contacts decreasing from a high of 36 to a low of 23 coincides with a lack of policy prominence at the national level, placement within the state government hierarchy can illustrate the declining stature of these offices at the state level. One office in the current study reported that prior to 2008 the director was housed in the governor's office and reported directly to the governor; however, subsequent to that time, the office has been moved to the state's Department of Corrections and deals primarily with programs for prisoners.

Some offices still report directly to the governor of the state with others reporting to a Cabinet member or having no reporting requirements outside of compliance with granting agencies. Other offices have even more distance from the governor's office. This shift in bureaucratic location demonstrates a potential change in priority, which might ultimately impact the number of dollars and staff dedicated to FBNP services. Reporting structures demonstrate the priority of FBNP within state governments and the further away these offices are from the governor, they potentially lose both power and revenue as a result. If the strength of these offices lies in their symbolic power as Sager (2010) contends, movement downward in the state hierarchy combined with lesser acknowledgement of their importance as partners by the federal office demonstrates a diminishing symbolic potency.

Those liaisons following the nonprofit model rather than being embedded in state governmental agencies or the governor's office (ASPE Research Brief 2009) are somewhat shielded from political changes operating outside of government. Although they have the ability to raise private funds, only one of the liaisons responding to the survey sought donations. This respondent wrote the office "had previously operated under a federal grant (ending in 2009), now it relies on the support of the private sector, which consequently resulted in their elimination of the position of Director." They were able to keep functioning but lost staff capacity to accomplish the work. Like many nonprofit organizations, this state 
liaison demonstrates the potential instability of grant funding in the wake of changing federal priorities and the opportunities and challenges private support provided.

\section{Limitations of the study}

For the quantitative model, utilizing the White House report for variables on federal funds expended to state organizations carries the risk of bias and potential inaccuracy; however, these are the only figures for funding specifically provided under the FBCI umbrella and that delineate secular as opposed to faith-based monies. In addition, data regarding how much funds were received by FBCI in a state prior to and after the office's creation would be beneficial and allow for an analysis of change in funding over time. On the survey analysis, the volunteer nature of the responses may represent a selection bias which a fuller response would help remedy. Those office directors who perceived their offices as doing well may be more inclined to respond than others who might be concerned about the office's performance.

\section{Areas for further study}

Because the faith-based funding determinants are largely inexplicable with the variables presented in this model, it raises fascinating questions regarding what constitutes faith-based and why the faith element is not a significant factor in funding decisions. One possible explanation could stem from the fact that under the current system of grant applications, organizations simply check a box to self-state whether or not they are faith-based.

This self-attesting has three potential outcomes: (1) an organization may identify itself as accurately as possible, (2) an organization with a faith-based component in its mission might choose to represent itself as more secular for fear of being discriminated against in the selection process, or (3) an organization with only minimal faith-based components might represent itself as faithbased in hopes that affiliation will increase the favorable receipt of a grant proposal.

Further research could analyze which organizations checked the faith-based box in light of typologies of faith-based organizations (Bielefeld and Cleveland 2013a; Schneider and Wittberg 2011; Smith and Sosin 2001; Sider and Unruh 2004) to ascertain the accuracy of such labels for organizations. This method of self-disclosure is problematic not only because of the identification dilemmas it 
presents but also because of the definitional difficulties regarding faith-based organizations. Since there is a wide continuum in terms of how much "faith" is injected in so-called faith-based organizations, it is difficult to parse out a definitive group of organizations falling under the faith-based category (Bielefeld and Cleveland 2013a). ${ }^{13}$

Other considerations for future research include the impact of the structure of the state contact, whether housed in government or in a nonprofit organization, on programmatic goals. Further analysis is also necessary to evaluate the stated goals and objectives for these offices aside from funding objectives.

\section{Conclusions and policy considerations}

State FBNP contacts have the potential to impact grassroots service providers in multiple positive ways, and whether or not they are reaching their objectives for organizations in terms of funding assistance is important for the bureaucrats providing the service, the organizations working on the ground, and the federal administration that set the plan in motion. The quantitative analysis of this article indicates that liaisons are ineffective relative to demographic and redistributional factors in pulling federal funding to faith-based and community organizations within their states. The follow-up survey results indicate a lack

13 Those favoring charitable choice often cite the inequality faced by nonprofit organizations of faith that provide public goods and services without the advantage of governmental support (Sider and Unruh 2000) and espouse that organizations of faith do a better job of providing human services than secular nonprofits (Green and Sherman 2002), although the evidence regarding the latter judgment is inconclusive as will be discussed later. Opponents of charitable choice cite separation of church and state arguments, note the complexities of compliance with federal funding regulations, and posit the fear that governmental funding will alter the character of FBOs and their services (Elliott 2003; Rogers 2000). Neither side necessarily follows standard lines of demarcation in terms of political party, conservative or liberal views, religious affiliation, or race (Robert Wuthrow 2004). Alliances formed of members from both sides of the political spectrum have supported governmental funding of FBOs and opponents, such as the Southern Baptist Convention have emerged. Because the term faith-based is nebulous, determining whether or not an organization can be considered faith-based is somewhat subjective. Some scholars have recommended using other terminology or typologies to describe more accurately the work of human service organizations with religious affiliations or ties. Jeavons (2004) protests that using "faith-based" presumes too much of a Judeo-Christian background and recommends using the term "religious" or "religiously-based" as replacement. Smith and Sosin (2001) refer to these nonprofits as "faith-related" rather than faith-based. Others prefer referencing organizations as "religiously affiliated" or other terminology which points to an organizational link to a particular spiritual or religious ideology. 
of funding and staff for these offices at the state level, attributable to reliance on federal grants, multi-tasking office structures, and declining political salience. Unless these trends change, state contacts will continue to have difficulty accomplishing their funding goals for grassroots organizations.

Not only does this study make new headway in applying multiple grants funding criteria to nonprofit studies it also offers practical points to ponder for bureaucrats and policy analysts concerning financial decision-making within state and federal governments and within nonprofit organizations. State FBCI/ FBNP offices and liaisons seek to provide a variety of services and profess to assist nonprofit service providers in finding and acquiring federal funds, but they are stymied in those pursuits. Offices are often short-staffed and receive paltry funds in comparison to other state program offices. They are located in a variety of different places in state government and often are run by individuals with a myriad of simultaneous responsibilities and duties.

Finally, federal attention has shifted to other policy foci. Impactful programming and long-term sustainability are difficult in such an environment, and evidence indicates that FBNP offices and liaisons may already be succumbing to the weight of these combined forces. Data from the Obama administration indicate that several states have dismantled their FBCI offices and have not transitioned the office to the new FBNP umbrella. ${ }^{14}$

Yet, even if all of the state offices and liaisons disbanded tomorrow, this study still has important ramifications for nonprofits in general and faith-based and community nonprofits specifically. While the constitutionality of faith-based funding by the federal government may be debated for years, FBCI as purveyors of social services have been, and are likely to continue to be, partners with government. As governmental support of social services continues to grow, this relationship is likely to be enhanced, not diminished.

Even within a precarious economic climate, the American Recovery and Reinvestment Act of 2009 set aside $\$ 50$ million in matching grant money to support faith-based and secular nonprofits under two programs, the Nonprofit Capacity-Building Program and the State, Local, and Tribal Government Capacity-Building Program (Wright 2010). Both programs are designed to assist community and faith-based organizations in providing services to those suffering from economic disparities. In such an atmosphere, it is particularly important to know that programmatic priorities including the need of a state, not

14 Information derived from the White House Office of Faith-Based and Neighborhood Partnerships homepage regarding state contacts at http://www.whitehouse.gov/administration/eop/ofbnp/offices/states accessed on December 3, 2009. 
political forces, determine federal funding decisions for faith-based and community organizations.

Although these offices are currently not assisting community organizations to access federal funding on a broad scale, it appears that the FBNP liaisons in the state are much like the organizations they serve, accomplishing what they can with very little resources. Many of the services they provide are low-cost, primarily information brokering through web sites. State-level offices with greater budgets are generally tied to federal grant programs, indicating potential problems with mission drift and their long-term stability within state governments. With general funds in short supply and a reliance on federal funding programs, such agencies cannot accomplish much more than the information sharing activities which currently predominate the FBNP activities. Outside of federal grant program activity, such offices have little resources to carry out projects and conduct outreach, and other research indicates that the offices are not yet forming sustainable collaborations or partnerships (Bielefeld and Cleveland 2013b; Campbell 2011) which might help increase outreach and the ability to provide services.

All of the evidence presented indicates that the state FBNP offices are potentially in a precarious position, both financially and politically. To make the state offices more effective in helping garner federal resources for community organizations within their states, government and nonprofit liaisons need to have adequate funding and dedicated staff; otherwise, there is little hope for them to produce greater financial substance for the community organizations they serve.

\section{Appendix}

State-level FBNP Office Survey Questions*

1. How was this office formed (legislation or executive order)?

2. How many staff work within the FBNP office?

2a. Of those, how much time is allocated to FBNP specifically? Is it,
A. $0-20 \%$
B. $21-40 \%$
C. $41-60 \%$
D. $61-80 \%$
E. $81-100 \%$

2b. Of those whose time is also allocated elsewhere, what other types of program(s) are their other time directed toward?

3. What is the reporting structure of your FBNP office?

4. What types of services and activities does the FBNP office perform? 
5. What is the current budget for the FBNP office in your state?

5a. Where does the budget originate from?

5b. How is the budget allocated among FBNP services and activities?

6. Has the office's work or focus changed from the Bush Administration to the Obama Administration?

6a. If yes, how?

7. How does your office interact with the White House Office of Faith-Based and Neighborhood Partnerships?

8. Does your office interact directly with federal agencies?

8a. If yes, what agencies and how?

9. Is the FBNP office in your state governed by any external advisory councils, boards, or commissions?

9a. If yes, please name the governing body and describe its composition?

10. What are the reporting requirements for your office?

\section{References}

Alperovich, G. 1984. "The Economics of Choice in the Allocation of Intergovernmental Grants to Local Authorities." Public Choice 44(2):285-96.

ASPE Research Brief. 2009. "The Role of State Faith Community Liaisons in Charitable Choice Implementation: Practice Models from the States." Office of the Assistant Secretary for Planning and Evaluation. Office of Human Services Policy. U.S. Department of Health and Human Services.

Bartkowski, J. P. 2001. The Promise and Peril of Charitable Choice: Faith-Based Initiatives in Mississippi. Cambridge, MA: Harvard.

Bartkowski, J. P., and H. A. Regis. 1996a. Charitable Choice and the Feasibility of Faith-Based Welfare Reform in Mississippi: Final Report Submitted to the Joint Center for Poverty Research. Evanston and Chicago: JCPR at Northwestern University and University of Chicago.

Bartkowski, J. P., and H. A. Regis. 1996b. Religious Organizations, Anti-Poverty Relief, and Charitable Choice: A Feasibility Study of Faith-Based Welfare Reform in Mississippi. Arlington: Pricewaterhouse Coopers Endowment for the Business of Government.

Berry, W. D., E. J. Ringquist, R. C. Fording, and R. L. Hanson. 1998. "Measuring Citizen and Government Ideology in the American States, 1960-93." American Journal of Political Science 42(1):327-48.

Bickers, K. N., and R. M. Stein. 2004. "Interlocal Cooperation and the Distribution of Federal Grant Awards." The Journal of Politics 66(3):800-22.

Bielefeld, W., and W. Cleveland. 2013a. "Defining Faith-Based Organizations and Understanding Them Through Research." Nonprofit and Voluntary Sector Quarterly 42:442-67.

Bielefeld, W., and W. Cleveland. 2013b. "Faith-Based Organizations as Service Providers and Their Relationship to Government." Nonprofit and Voluntary Sector Quarterly 42:468-94. 
Black, A. E., D. L. Koopman, and D. K. Ryden. 2004. Of Little Faith: The Politics of George W. Bush's Faith-Based Initiatives. Washington, DC: Georgetown University Press.

Campbell, D. E. 2011. "Reconsidering the Implementation Strategy in Faith-Based Policy Initiatives." Nonprofit and Voluntary Sector Quarterly 40:130-48.

Carlson-Thies, S. W. 2004. "Implementing the Faith-Based Initiative." The Public Interest 155:57-74.

Cnaan, R., and E. Newman. 2010. "The Safety Net and Faith-Based Services.” Journal of Religion \& Spirituality in Social Work: Social Thought 29:321-36.

Dionne, E. J, Jr., and J. J. Jr. Dilulio. (eds.). 2000. What's God Got to Do With the American Experiment? Washington, DC: Brookings Institute Press.

Elliott, B. F. 2003. The Roots of American Compassion. Indianapolis, IN: Hudson Institute.

Engstrom, E., and G. Vanberg. 2007. "The Politics of Congressional Earmarking." Unpublished University of North Carolina.

Farris, A., Nathan, R.P., and Wright, D.J. 2004. The expanding presidency: George W. Bush and the Faith-Based Initiative. A Project of the Rockefeller Institute of Government. Roundtable on Religion and Social Welfare Policy. Pew Research Religion \& Public Life Project. http://www.rockinst.org/pdf/federalism/2004-08-the_expanding_ administrative_presidency_george_w_bush_and_the_faith-based_initiative.pdf Accessed November 15, 2013.

Gist, J. R., and R. C. Hill. 1981. "The Economics of Choice in the Allocation of Federal Grants: An Empirical Test.” Public Choice 36:63-73.

Green, J. C., and A. Sherman. 2002. Fruitful Collaborations: A Survey of Government-Funded Faith-Based Programs in 15 States. Charlottsville, VA: Hudson Institute, Inc. and University of Akron.

Gronbjerg, K. A. 1993. Understanding Nonprofit Funding: Managing Revenues in Social Services and Community Development Organizations. San Francisco, CA: Jossey-Bass Publishers.

Hall, J. 2008. "Assessing Local Capacity for Federal Grant-Getting." American Review of Public Administration 38:438-79.

Hall, J. 2010. "The Distribution of Federal Economic Development Grant Funds: A Consideration of Need and the Urban/Rural Divide." Economic Development Quarterly 24(4):311-24.

Holcombe, R. G., and A. Zardkoohi. 2001. "The Determinants of Federal Grants." Southern Economic Journal 48(2):393-9.

Jeavons, T. H. 2004. "Religious and Faith-Based Organizations: Do We Know One When We See One?" Nonprofit and Voluntary Sector Quarterly 33:109.

Jennings, E. T., D. Krane, A. N. Pattakos, and B. J. Reed. 1986. From Nation to States: The Small Cities Community Development Block Grant Program. Albany, NY: State University of New York Press.

Kaplowitz, M. D., T. Hadlock, and R. Levine. 2004. "A Comparison of Web and Mail SurveyResponse Rates.” Public Opinion Quarterly 68(1):94-101.

Kennedy, S. S. 2003. Charitable Choice: First Results From Three States. Indianapolis, IN: Center for Urban Policy and the Environment, School of Public and Environmental Affairs, Indiana University-Purdue University.

Kennedy, S., and W. Bielefeld. 2006. Charitable Choice at Work: Evaluating Faith-Based Job Programs in the States. Washington, DC: Georgetown UP.

Kinney, N. T. 2006. "Toppling Jefferson's Wall or Tiptoeing Around It? Evaluating the Imlementation of Faith-Friendly Welfare Policy." Administration \& Society 38:3-4. 
Kramer, F. D., D. Finegold, C. J. DeVita, and W. Laura. 2005a. "Implementing the Federal FaithBased Agenda: Charitable Choice and Compassion Capital Initiatives." [Electronic Version]. New Federalism: Issues and Options for States A-69:1-7. Retrieved September 20, 2007.

Kramer, F. D., K. Finegold, C. J. DeVita, and L. Wherry. 2005b. "Federal Policy on the Ground: Faith-Based Organizations Delivering Local Services." [Electronic Version]. Assessing the New Federalism: An Urban Institute Program to Assess Changing Social Policies 05-01:196. Retrieved August 7, 2007.

Luksetich, W. 2008. "Government Funding and Nonprofit Organizations." Nonprofit and Voluntary Sector Quarterly 37(3):434-42.

Montiel, L. M., and D. J. Wright. 2006. Getting a Piece of the Pie: Federal Grants to Faith-Based Social Service Organizations. Albany, NY: The Roundtable on Religion and Social Welfare Policy.

Pipes, P. F., and H. R. Ebaugh. 2002. "Faith-Based Coalitions, Social Services and Government Funding." Sociology of Religion 63(1):49-68.

President's Advisory Council on Faith-Based and Neighborhood Partnerships. 2010. A New Era of Partnerships: Report of Recommendations to the President. March. Available at: http:// www.whitehouse.gov/administration/eop/ofbnp/about/council.

Preston, A. 2007. "Volunteer Resources." In Financing Nonprofits: Putting Theory Into Practice, edited by D. R. Young, 183-206. Lanham: Altamira Press.

Rich, M. J. 1989. "Distributive Politics and the Allocation of Federal Grants." The American Political Science Review 83(1):193-213.

Rogers, M. 2000. "The Wrong Way to Do Right: A Challenge to Charitable Choice." In What's God Got to Do with the American Experiment? edited by E. J. Dionne Jr. and J. J. Dilulio Jr., 138-45. Washington, DC: Brookings Institute Press.

Rushton, M., and A. C. Brooks. 2007. "Government Funding of Nonprofit Organizations." In Financing Nonprofits: Putting Theory into Practice, edited by D. R. Young, 69-92. Lanham, MD: Altamira Press.

Sager, R. 2007. "The Importance of State Faith-Based Liaisons." Sociology of Religion 68(1):97-109.

Sager, R. 2010. Faith, Politics, and Power: The Politics of Faith-Based Initiatives. Oxford: Oxford UP.

Schneider, J. A. 2013. "Introduction to the Symposium: Faith-Based Organizations in Context." Nonprofit and Voluntary Sector Quarterly 42:431-41.

Schneider, J. A., and P. Wittberg. 2011. "Comparing Practical Theology Across Religions and Denominations." Journal of the Religious Research Association 52:405-26.

Searle, S. D., A. Mitniski, E. A. Bahbauer, T. M. Gill, and K. Rockwood. 2008. "A Standard Procedure for Creating a Frailty Index." BMC Geriatrics 8:24.

Sider, R. J., and H. Unruh. 2000. "No Aid to Religion? Charitable Choice and the First Amendment." In What's God Got to Do with the American Experiment? edited by E. J. Dionne Jr. and J. J. Dilulio Jr., 128-37. Washington, DC: Brookings Institute Press.

Sider, R. J., and H. Unruh. 2004. Typology of Religious Characteristics of Social Service and Educational Organizations and Programs. Nonprofit and Voluntary Sector Quarterly 33(109).

Sinha, J. 2013. "Unintended Consequences of the Faith-Based Initiative: Organizational Practices and Religious Identity with in Faith-Based Human Service Organizations." Nonprofit and Voluntary Sector Quarterly 42:563-83.

Smith, S. R., and M. R. Sosin. 2001. "The Varieties of Faith-Related Agencies." Public Administration Review 61(6):651-70. 
Solomon, L. D. 2003. In God We Trust? Faith-Based Organizations and the Quest to Solve America's Social Ills. Lanham: Lexington Books.

Steenbergen, M. R., A. Bachtiger, M. Sporndli, and J. Steiner. 2003. "Measuring Political Deliberation: A Discourse Quality Index." Comparative European Politics 1:21.

Stein, R. M. 1981. "The Allocation of Federal Aid Monies: The Synthesis of Demand-Side and Supply-Side Explanations." The American Political Science Review 75(2):334-43.

White House Office of Faith-Based and Community Initiatives. 2004. Grants to Faith-Based Organizations FY 2003. Washington, DC.

White House Office of Faith-Based and Community Initiatives. 2008a. The President's FaithBased and Community Initiative in 50 States: A Report to the Nation's Governors. February. White House Office of Faith-Based and Community Initiatives. 2008b. The President's FaithBased and Community Initiative in 50 States: A Report to the Nation. June.

Worthington, A. C., and B. E. Dollery. 1998. "The Political Determination of Intergovernmental Grants in Australia." Public Choice 94:299-315.

Wright, D. J. 2010. Taking Stock: The Bush Faith-Based Initiative and What Lies Ahead. The Roundtable on Religion and Social Welfare Policy.

Wuthrow, R. 2004. Saving America? Faith-Based Services and the Future of Civil Society. Princeton, NJ: Princeton University Press.

Young, D. R. (ed.). 2007. Financing Nonprofits: Putting Theory into Practice. Lanham, MD: Altamira Press. 
